\section{A Large Sunspot Group}

ON April 8, a pair of large sunspots, with smaller attendant spots, came into view around the sun's north-east limb. The group crossed the sun's central meridian on April $14 \cdot 1$ U.T. and will reach the western limb on April 20. The latitude of the group is $27^{\circ}$ north, and its area on April 8 was 1,500 millionths of the sun's visible hemisphere. Sunspots of this size are found to show, statistically, a marked association with the occurrence of terrestrial magnetic storms, the storm commencing on the average about one day after the time of central meridian passage of the associated sunspot.

\section{Announcements}

THE Kelvin Medal Award Committee announces that the Kelvin Medal for 1938 has been awarded to Sir Joseph J. Thomson, and that the presentation will be made by Lord Rayleigh in the Great Hall of the Institution of Civil Engineers, on Tuesday, May 3, at 5 p.m.

DR. W. T. Carman, formerly keeper of zoology in the British Museum (Natural History), has been elected an honorary member of the Société Zoologique de France.

THE following have been elected associates of the Royal Astronomical Society: M. L. d'Azambuja, Meudon Observatory, France ; Prof. A. O. Leuschner, director of the Students' Observatory, Berkeley, California, and professor of astronomy in the University of California ; Prof. Knut Lundmark, director of the Lund Observatory and professor of astronomy in the University of Lund.

M. ROBERT COURRIER has been nominated professor of experimental morphology and endocrinology at the Collège de France.

Lieut.-Colonel J. H. M. Greenly has been appointed president of the Institute of Fuel in succession to Sir Philip Dawson, as from October 13 next. Colonel Greenly, who has been a vicepresident of the Institute for the past few years, is the chairman of Messrs. Babcock and Wilcox, Ltd. ; he is also a member of the Advisory Council to the Committee of the Privy Council for Scientific and Industrial Research, and chairman of the British Non-Ferrous Metals Research Association.

THE following appointments and promotions have recently been made in the Colonial Service : K. M. Francis, European assistant, East African Meteorological Service, East Africa; J. P. Henderson, European assistant, East African Meteorological Service, East Africa; R. G. Ffoulkes-Jones, second assistant petroleum technologist, Trinidad; R. R. Waterer (assistant conservator of forests), conservator of forests, Cyprus ; W. E. Bassett (assistant agricultural officer, Agricultural Department, Dominica), curator, Agricultural Department, Montserrat, Leeward Islands; C. J. M. Krige (senior agricultural assistant), agricultural officer, Tanganyika.
The annual Conference of the Institute of Public Cleansing will be held in Glasgow on June 13-17.

THE eighth International Congress for Logopædics and Phoniatrics will be held at Salzburg on July 28-30. Further information can be obtained from the president, Ferstelgasse 6, Wien ix.

THE eighth Netherlands Indies Congress of Natural Science will be held at Soerabaja on July 20-23 and will consist of sections devoted to mathematics, natural history, physics, medicine, biology, chemistry, veterinary science, geology and geography. Further information can be obtained from the general secretary, Dr. H. W. Lubberhuizen, Embong Kemiri 4, Soerabaja.

THE seventh International Congress of Entomology will be held in Berlin on August 13-20, and will consist of a general section and a special section, the latter comprising a subsection of medical and veterinary entomology. The president will be Prof. E. Martini of Hamburg. Further information can be obtained from the general secretary, Dr. Hering, Zoologisches Museum, Invalidenstrasse 43, Berlin, N.4.

A HEALTH congress of the Royal Sanitary Institute will be held at Portsmouth on July 11-18 under the presidency of Lord Bessborough. Sections will be allotted to preventive medicine, architecture, town planning and engineering, maternity and child welfare and school hygiene, veterinary hygiene, national health insurance, hygiene of food, and tropical hygiene. Conferences of local authorities, medical officers of health, engineers, surveyors, sanitary inspectors and health visitors will also take place during the Congress. Further information can be obtained from the Secretary of the Institute, 90 Buckingham Palace Road, S.W.1.

WE have received a copy of the complete, official list of the British papers which are being prepared for presentation at the sectional meeting of the World Power Conference to be held in Vienna on August 25-September 2. Copies of the technical programme may be obtained now, and copies of the general programme, time-table and membership application form will be obtainable in due course, from the British National Committee, World Power Conference, 36 Kingsway, London, W.C.2.

ERratum. In the article "Scientific Work of the Drifting North Polar Station" published in NaTuRE of April 9, pp. 629-632, it should have been stated that the distances quoted in English units were in nautical miles. On p. 629 , col. 2 , line 4, the distance covered by the drift was 1,134 nautical miles (2089 $\mathrm{km}$.$) ; line 11, the average drift of the floe was$ $9 \cdot 1 \mathrm{~km}$. (4.9 nautical miles) a day; line 15 , the daily drift was sometimes 23 nautical miles (42 km.) a day. 